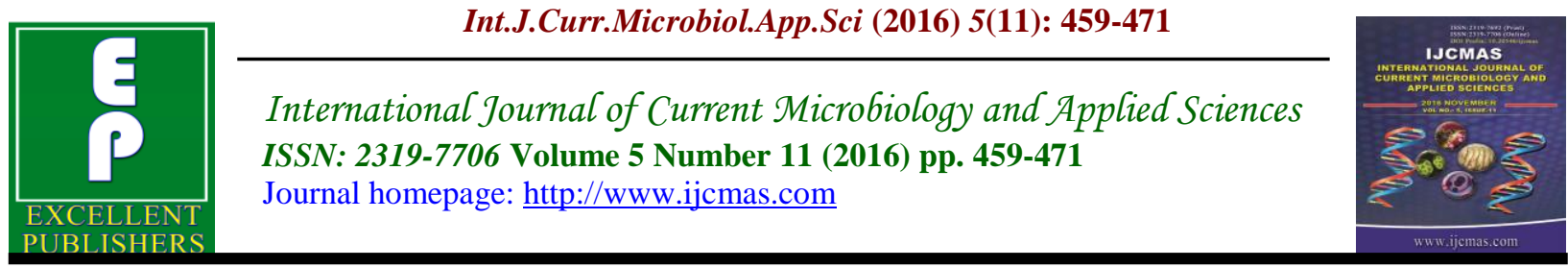

Review Article

http://dx.doi.org/10.20546/ijcmas.2016.511.053

\title{
Study of Genetic Determinants of Nickel and Cadmium Resistance in Bacteria-A Review
}

\author{
Santanu Maitra* \\ Department of Microbiology, Ramakrishna Mission Vidyamandira, \\ Belur Math, Howrah-711202, India \\ *Corresponding author
}

\begin{tabular}{|c|c|}
\hline & A B S T R A C T \\
\hline Keywords & \multirow{3}{*}{$\begin{array}{l}\text { Microorganisms are ubiquitous in nature and are involved in almost all } \\
\text { biological processes of life. With rapid urbanization and natural processes, } \\
\text { heavy metals have been found in increasing proportions in microbial } \\
\text { habitats. Metals have been known to play a major role either directly or } \\
\text { indirectly in almost all metabolic processes, growth and development of } \\
\text { microorganisms. Bacteria that are resistant to such heavy metals and have } \\
\text { the ability to grow in high concentrations of these metals play an important } \\
\text { role in their biological cycling which has great potential in bioremediation } \\
\text { of poorly cultivable soil high in heavy metal content. This review describes } \\
\text { the compilation of Nickel and Cadmium metal-resistance systems in } \\
\text { bacteria. }\end{array}$} \\
\hline Article Info & \\
\hline $\begin{array}{l}\text { Accepted: } \\
23 \text { October } 2016 \\
\text { Available Online: } \\
\text { 10 November } 2016\end{array}$ & \\
\hline
\end{tabular}

\section{Introduction}

Heavy metals, having specific weight more than $5.0 \mathrm{~g} / \mathrm{cm}^{3}$, are generally categorized in three classes: toxic metals (e.g. $\mathrm{Hg}, \mathrm{Cr}, \mathrm{Pb}$, $\mathrm{Zn}, \mathrm{Cu}, \mathrm{Ni}, \mathrm{Cd}, \mathrm{As}, \mathrm{Co}, \mathrm{Sn}$, etc.), precious metals (e.g. $\mathrm{Pd}, \mathrm{Pt}, \mathrm{Ag}, \mathrm{Au}, \mathrm{Ru}$, etc.) and radionuclides (e.g. U, Th, Ra, Am, etc.) (Nies, 1999; Bishop, 2002). Worldwide, smelting of metalliferous surface finishing industry, fertilizer and pesticide industry, sewage sludge, energy and fuel production, mining, agriculture, leatherworking, metallurgy, combustion of fossil fuels, electroplating, faulty waste disposal, electrolysis, electro-osmosis, photography, electric appliance manufacturing, metal surface treatments, aerospace and atomic energy installation and military operations have directly or indirectly released huge amounts of toxic heavy metals into the environment with a subsequent hazardous impacts on both ecological and human health principally in developing countries (Wang and Chen, 2006; Kotrba et al., 2009; Ahemad and Malik, 2011). Heavy metal toxicity to various environmental niches is a great concern for environmentalists. Because these metals are difficult to be eliminated from the environment and unlike many other pollutants cannot be degraded chemically or biologically and are eventually indestructible and hence, their toxic effects last longer (Ahemad, 2012). Moreover, heavy metals display toxicity at low concentration (1.0-10 $\mathrm{mg} / \mathrm{L})$. 
Surprisingly, $\mathrm{Hg}$ and $\mathrm{Cd}$ metal ions show toxicity even at concentration of $0.001-0.1$ $\mathrm{mg} / \mathrm{L}$. Furthermore, some metals (e.g. Hg) may transform from less toxic species into more toxic forms under some environmental conditions (Wang and Chen, 2006; Alkorta et al., 2004). The metal concentration accumulated in soil is dependent upon the level of industrial discharge laden with metal species, the transportation of metals from the source to the disposing site and the retention of metals once these are reached (Ahemad, 2012; Alloway,1995). Although some of the heavy metals are required by organisms at low concentration and are essential for different metabolic activities (Adriano, 2001). For instance, zinc is the component of a variety of metalloenzymes or it may act as cofactor for several enzymes (dehydrogenases, proteinases, peptidases, oxidase) (Hewitt et al., 1983). Moreover, it is also required for the metabolism of carbohydrates, proteins, phosphates, auxins, RNA and ribosome formation in plants (Shier, 1994).

Likewise, copper at low concentration, contributes to several physiological processes, such as, photosynthesis, respiration, carbohydrate distribution, nitrogen synthesis, cell wall metabolism and seed production in plants (Kabata-Pendias et al., 2001). However, the elevated concentration of such metals above threshold levels in soils negatively affects the composition of microbial communities including Plant Growth Promoting Bacteria (PGPB) both quantitatively and qualitatively (Wani et al., 2008; Ahemad and Khan, 2012) which in turn, leads to substantial changes in ecological dynamics of rhizosphere niche (Gray, 2005). In addition, the higher concentration of metals not only affects the growth and metabolism but also decreases the biomass of naturally occurring soil microbial communities of beneficial microorganisms around the roots (Giller et al., 1998; Pajuelo et al., 2008). As well, they also exert a negative impact on plant growth (Rajkumar et al., 2006; Wani and Khan, 2010). For example, cadmium halts the enzymatic activities, DNA-mediated transformation, symbiosis between microorganisms and plants and makes the plant prone to fungal attack (Kabata-Pendias et al., 2001; Wani et al., 2008). The remediation of metal-contaminated soils consequently becomes imperative, because such soils generally cover large areas that are rendered inappropriate for sustainable agriculture. Soil is a complex ecosystem where different microorganisms play important roles in maintaining the soil fertility and plant productivity through the interactions with both biological and physico-chemical components (Ahemad et al., 2009; Ilieva et al., 2014; Kosev et al., 2014). Under metal stress, soil microorganisms including Plant Growth Promoting Bacteria (PGPB) have developed many strategies to evade the toxicity generated by the various heavy metals. These mechanisms include the expulsion of metal species outside the microbial cell surface, bioaccumulation the metal ions inside the cell actively or passively, biotransformation of toxic metals to less toxic forms and metal adsorption on the cell wall (Ahemad and Khan, 2012).

Therefore, bacterial strains isolated from polluted environments were shown to be tolerant to higher concentrations of metals than those isolated from unpolluted areas (Rajkumar et al., 2010). Through these metal stress evading mechanisms, PGPB, when used as bioinoculant or biofertilizers, substantially improved the growth of plants implanted in heavy metal contaminated/ stressed soils by lowering the metal toxicity (Wani and Khan, 2010; Madhaiyan et al., 2007). 


\section{Mechanisms to overcome metal stress in bacteria}

It is well known that heavy metal cations are essentially required as trace elements to carry out the various biochemical reactions in microbial cell metabolism (Ahemad and Khan, 2012). However, heavy metal ions form unspecific complexes in the microbial cells at concentrations above threshold levels thereby toxic effects of these metals are manifested. For example, heavy metals like, $\mathrm{Hg}^{+2}, \mathrm{Cd}^{+2}$ and $\mathrm{Ag}^{+}$form highly toxic complexes which adversely affect the physiological functions of bacteria cells (Nies, 1999). Metal concentration exceeding the biological requirement inhibits the bacterial growth or bacteria respond to the elevated levels of metals by various resistance mechanisms (Ahemad and Malik, 2011). For instance, an in vitro assessment of the sensitivity of plant growth promoting Rhizobium, Bradyrhizobium and Pseudomonas to $\mathrm{Cu}^{+2}, \mathrm{Co}^{+2}, \mathrm{Mn}^{+2}, \mathrm{Mo}^{+2}$ and $\mathrm{Fe}^{+2}$ by Biro' et al.(1995) revealed that Rhizobium leguminosarum stains were most sensitive to $\mathrm{Cu}^{+2}, \mathrm{Zn}^{+2}$ and $\mathrm{Co}^{+2}$ while Bradyrhizobium, Pseudomonas isolates, however, tolerated the highest $(10 \mu \mathrm{g} / \mathrm{ml})$ dose of these metals. This study also showed that sulfate forms of $\mathrm{Cu}^{+2}$ and $\mathrm{Zn}^{+2}$ were more deleterious than the chloride counterparts. Generally, long term exposure of heavy metals to microorganisms enforces a selection pressure which facilitates the proliferation of microbes, tolerant/resistant to metal stress. This adaptive mechanism of metal resistance has been explored by assaying habitats exposed to anthropogenic or natural metal contamination over an extended period of time (Hutchinson et al., 1997), or by experimentally adding heavy metals to samples, and assaying changes over periods up to a few years (Diaz-Ravina et al., 1996). Hence, metal entry within the bacterial cell is first prerequisite to manifest the metal toxicity. Generally, bacterial cells uptake the heavy metal cations of the similar size, structure and valency with the same mechanism (Nies, 1999). Bacteria generally possess two types of uptake system for heavy-metal ions: one is fast and unspecific and driven by the chemiosmotic gradient across the cytoplasmic membrane and another type is slower, exhibits high substrate specificity, and is coupled with ATP hydrolysis (Nies et al., 1995). Bacteria including PGPB have devised several resistance mechanisms, by which they can immobilize, mobilize or transform metals, thus reducing their toxicity to tolerate heavy metal ion uptake (Ahemad, 2014). The major mechanisms are physical sequestration, exclusion, complexation and detoxification etc. In fact, binding of heavy metals to extracellular materials can immobilize the metal and further, prevent its intake into bacterial cell. For instance, many metals bind the anionic functional groups (e.g. sulfhydryl, carboxyl, hydroxyl, sulfonate, amine and amide groups) present on cell surfaces. Likewise, bacterial extracellular polymers, such as polysaccharides, proteins and humic substances, also competently bind heavy metals (biosorption) (Ahemad et al., 2013). These substances thus detoxify metals merely by complex formation or by forming an effective barrier surrounding the cell (Rajkumar et al., 2010). Moreover, siderophores secreted by a range of PGPB can also diminish metal bioavailability and in turn, its toxicity by binding metal ions that have chemistry akin to that of iron (Gilis et al.,1998; Dimkpa et al., 2008; Rajkumar et al., 2010). Sometimes, crystallization and precipitation of heavy metals takes place because of bacteriamediate reactions or due to the production of specific metabolites (Diels et al., 2003; Rajkumar et al., 2010). Furthermore, numerous bacteria exhibit efflux transporters 
(e.g. ATPase pumps or chemiosmotic ion/proton pumps) with high substrate affinity by which they expel high concentration of toxic metals outside the cell (Ahemad, 2012; Haferburg et al., 2007). For instance, plasmid encoded and energy dependent metal efflux systems involving ATPases and chemiosmotic ion/proton pumps are also reported for arsenic, chromium and cadmium resistance in other bacteria. Moreover, several bacteria have developed a cytosolic sequestration mechanism for protection from heavy metal toxicity. In this process, metal ions might also become compartmentalized or converted into more innocuous forms after entering inside the bacterial cell. This process of detoxification mechanism in bacteria facilitates metal accumulation in high concentration (Ahemad, 2012; Haferburg et al., 2007). For this, a marvelous example is the synthesis of lowmolecular mass cysteine-rich metal-binding proteins, metallothioneins which have high affinities for cadmium, copper, silver and mercury, etc. The production of these novel metal detoxifying proteins is induced by the presence of metals. In addition, certain bacteria utilize methylation as an alternative for metal resistance or detoxification mechanism. It involves the transfer of methyl groups to metals and metalloids. However, limitation of application of this methylation related metal detoxification is that only some metals can be methylated (Rajkumar et al., 2010; Ranjard et al., 2003). In addition, microorganisms can eliminate several heavy metals from the metal polluted soils by reducing them to a lower redox state. Bacterial species that catalyze such reducing reactions are referred to as dissimilatory metal-reducing bacteria, exploit metals as terminal electron acceptors in anaerobic respiration; even though, most of them use $\mathrm{Fe}^{+3}$ and $\mathrm{S}^{0}$ as terminal electron acceptors (Lovley, 1995; Jing et al., 2007).
For example, the anaerobic or aerobic reduction of $\mathrm{Cr}(\mathrm{VI})$ to $\mathrm{Cr}(\mathrm{III})$ by an array of bacterial isolates is an effective means of chromium detoxification (Wang and Shen, 1995). Moreover, metal-chelating agents, siderophores secreted by different bacteria too have an important role in the acquisition of several heavy metals (Rajkumar et al., 2010).

\section{Study of genetic determinants of metal resistance}

\section{Resistance to Nickel}

Nickel enters the bacterial cell by the CorA system in bacteria and Saccharomyces cerevisiae (Hmiel et al., 1989; Snavely et al., 1989). An additional nickel transporter have been identified in Alcaligenes eutrophus (Lohmeyer and Friedrich, 1987) and later identified as part of the hydrogenase gene cluster (Eberz et al., 1989). Until recently, two major types of microbial high-affinity nickel and cobalt transporters were known: ATP-binding cassette (ABC) systems and secondary permeases of the NiCoT family (Nix A, UreH, HupN and HoxN) (Eitinger et al., 2005). The NikABCDE system of Escherichia coli belongs to the nickel/peptide/opine $\mathrm{ABC}$ transporter family and is composed of the periplasmic binding protein NikA, two integral membrane components (NikB and -C), and two ATPases (NikD and -E) (Navarro et al., 1993). Though distantly related ABC transporter systems from pathogenic Yersinia pseudotuberculosis and Brucella suis are also implicated in the high-affinity nickel uptake (Jubier-Maurin et al., 2001; Sebbane et al., 2002), many other representatives of this $\mathrm{ABC}$ transporter family are involved in uptake of other compounds, i.e., dipeptides and oligopeptides (Abouhamad et al., 1995; 
Levdikov et al., 2005). Nickel/cobalt permeases of the NiCoT family are widely distributed in bacteria and are also present in some archaea and fungi. The substrate preferences of many representatives have been analyzed in detail (Degen et al., 2002; Degen et al., 1999; Hebbeln et al., 2004). The NiCoT family includes at least one nickel-specific permease and many proteins with mixed metal ion specificities that have a preference for either nickel or cobalt ions. Two other families of putative secondary metal transporters, HupE/UreJ and UreH, are distantly related to NiCoTs, and certain members of these families have recently been shown to mediate nickel transport (Eitinger et al., 2005). HupE/UreJ proteins are widespread among bacteria and often encoded within $(\mathrm{NiFe})$ hydrogenase(HupE) and urease (UreJ) gene clusters. Subgroups of UreH proteins are found in marine cyanobacteria and in plants. The cyanobacterial variants are encoded adjacent to (Ni) superoxide dismutase genes predicting a role in nickel uptake. Smith (1967) first reported that nickel resistance in bacteria is plasmid mediated. The best known mechanism of nickel resistance has been extensively studied in the bacteria $A$. eutrophus $\mathrm{CH} 34$. The organism harbors two plasmids pMOL28 which is responsible for $\mathrm{Ni}, \mathrm{Hg}$ and $\mathrm{Cr}$ resistance and another plasmid pMOL30 which constitute the genetic determinants for $\mathrm{Cd}, \mathrm{Co}, \mathrm{Zn}, \mathrm{Hg}$ and $\mathrm{Cu}$ resistance (Mergeay et al., 1985; Nies et al., 1989; Mergeay, 1995) Nickel efflux driven by a RND transporter is the basis of resistance in this strain. Two operon systems have been studied, a nickel-cobalt resistance $\mathrm{Cnr}$ (cnrCBA structural resistance genes with cnr YXH regulatory genes) (Liesegang et al., 1993) and a nickel-cobalt-cadmium resistance, Ncc (Ncc CBA operon) (Schmidt and Schlegel, 1994). Ni resistance has been studied among other bacterial strains like $A$. eutrophus KT02 was isolated from the wastewater treatment plant of Göttingen (Timotius and Schlegel, 1987); it is a lithoautotrophic bacterium and harbors the following three plasmids: plasmid pGOE1 (250 kbp), which determines cadmium and zinc resistance, plasmid pGOE2 (210 kbp), which encodes nickel and cobalt resistance, and plasmid pGOE3 (170 kbp), for which no function is known (Schmidt et al., 1991). A. xylosoxidans $31 \mathrm{~A}$ was isolated from the metalworking industry in Holzminden, Germany. It is an organotrophic bacterium and harbors two large plasmids, pTOM8 (340 kbp) and pTOM9 (200 kbp), both of which determine resistance to nickel, cobalt, zinc, cadmium, and copper ions (Schmidt and Schlegel, 1989).Recently, there are two distinct nickel resistance loci on plasmid pTOM9 from Achromobacter xylosoxidans 31A, ncc and nre. Expression of the nreB gene was specifically induced by nickel and conferred nickel resistance on both $A$. xylosoxidans 31A and Escherichia coli. E. coli cells expressing nreB showed reduced accumulation of $\mathrm{Ni}$, suggesting that $\mathrm{NreB}$ mediated nickel efflux. The histidine-rich $\mathrm{C}$ terminal region of NreB was not essential but contributed to maximal $\mathrm{Ni}$ resistance (Grass et al., 2001). A. denitrificans 4a-2, isolated from the wastewater treatment plant in Dransfeld, Germany, and Klebsiella oxytoca CCUG 15788, isolated from the metalworking industry in Göttenberg, Sweden, are so far the only strains which have been shown to carry nickel resistance genes on the chromosome (Stoppel et al., 1995; Kaur et al., 1990). In E. coli, nickel overload is avoided via the repressor NikR, which binds to the promoter region of the nikABCDE operon when nickel is present (Chivers et al., 2000; De Pina et al.,1999). NikR has both strong (in the pM range) and weak (nM) Ni-binding sites, allowing sensing of nickel at concentrations corresponding to the range from 1 to 100 molecules per cell (Bloom et al., 2004). 
Other resistant genes in E.coli includethe rcnA (yohM) gene responsible for nickel and cobalt efflux (Rodrigue et al., 2005). In the unicellular cyanobacterium Synechocystis sp. PCC 6803, a nickel resistance operon ( $n r s B A C D)$ formed by four open reading frames (ORFs) has been described previously (García-Domínguez et al., 2000). NrsB and NrsA proteins are homologues to $\mathrm{CzcB}$ and $\mathrm{CzcA}$, respectively and they very probably form a membranebound protein complex catalysing $\mathrm{Ni}$ efflux by a proton/cation antiport. $\mathrm{NrsC}$ is not homologous to proteins encoded by the $c z c$ or related operons, and its role in $\mathrm{Ni}$ export is unknown. Finally, NrsD is a membrane protein belonging to the major facilitator superfamily of transport proteins. NrsD is highly homologous to NreB from Achromobacter xylosoxidans (Grass et al., 2001). In Cupriavidus metallidurans CH34 genome contains an ortholog of Atm1p named AtmA alongwith its cnr CBA operon(in C.metallidurans CH34) or ncc CBA operon (in C.metallidurans 31A). The atmA gene is located on chromosome 1 of strain $\mathrm{CH} 34$ and probably not part of an operon. Atm A increased Nickel and Cobalt resistance in both $C$. metallidurans and $E$. coli and probably worked in concert with other resistance operons (Mikolay et al., 2009). In other systems such as Helicobacter pylori Czn operons (Cd,Zn and $\mathrm{Ni}$ resistance)(a type of HME-RND transporter) (Stahler et al., 2006) or pNi15 plasmid coded nrp operon (containing Nrp A and B genes till date identified) found in Enterobacter sp. Ni15 (Lee et al., 2006) were also studied.

\section{Resistance to Cadmium}

Cadmium enters bacterial cells by the transport systems for essential divalent cations such as $\mathrm{Mn}^{2+}$ (Tynecka et al., 1981) or $\mathrm{Zn}^{2+}$ (Laddaga and Silver, 1985).
Microbial resistance to cadmium is usually based on energy-dependent efflux mechanisms (Silver, 1996). Microorganisms resist $\mathrm{Cd}$ by at least six different ways. These include enhanced transcription of metalothionein genes (McEntee et al., 1986), gene amplification (Beach and Palmiter, 1981), active Cd efflux (Tynecka et al., 1981), deposition of the toxic metal in the cell wall and altered accumulation of the toxic compound, alternation of the cell wallplasmamembrane complex (Mitra and Berstein, 1977). One of the bestcharacterized bacterial cadmium resistance mechanisms is determined by the cadmiumtransporting ATPase found initially in Grampositive bacteria (Silver and Phung, 1996). The cadmium-transporting ATPase is a Ptype ATPase, a member of the cationtransporting ATPases found in both Bacteria and Eucarya (Silver, 1996). It is widespread in S. aureus (Nucifora et al., 1989) and Listeria monocytogenes (Lebrun et al., 1994). The ATPase is encoded by cadA, which is usually plasmid-borne and associated with transposons in L. monocytogenes (Lebrun et al., 1992; Lebrun et al., 1994). The cadmium efflux genes in $S$. aureus are both plasmid-borne and chromosomal. The chromosomal locus of $S$. aureus is similar to cadAC of the plasmid-borne genes but confers resistance to low concentrations (MIC of $128 \mu \mathrm{g} / \mathrm{ml}$ ) of cadmium nitrate (Witte et al., 1986). CadC, encoded immediately downstream of $c a d A$, is a regulatory protein, which is also required for cadmium resistance in Grampositive bacteria. CadC binds to the promoter-operator area of the cadA gene and works as a transcriptional repressor in vitro (Endo and Silver, 1995). Another class of cadmium resistance genes in S. aureus includes $c a d B$ or the $c a d B$-like $c a d D$, which confers a different mechanism of resistance (Crupper et al., 1999). The function of $C a d B$ is not well defined, but it may protect 
bacterial cells by binding cadmium in the membrane. A positive response regulator gene, $\operatorname{cadX}$, was found in the $c a d B$-like operon on plasmid pLUG10 in $S$. lugdunensis. CadX is similar to CadC of the $c a d A$ operon but acts as a positive regulator. CadD of S. aureus is similar to $C a d B$ of S. lugdunensis. Hydropathy analysis of the CadD from plasmid pRW001 revealed transmembrane domains with potential cadmium cation-binding motifs in the cytosolic domain (Crupper et al., 1999). In B. subtilis $\mathrm{Cd}$ resistance is mediated through a mutation in the chromosome, which caused a change in the membrane $\mathrm{Mn}$ transport system and thereby prevented intracellular accumulation of $\mathrm{Cd}$ (Laddaga and Silver, 1985). In Gram-negative bacteria, Alcaligenes eutrophus, wellcharacterized cadmium resistance system is the cadmium, zinc, and cobalt ( $c z c)$ resistance determinant (Diels et al., 1995). The $\mathrm{CzcC}, \mathrm{CzcB}$, and $\mathrm{CzcA}$ proteins comprise an active efflux mechanism driven by a cation-proton antiporter, rather than a cation-transporting ATPase (Nies et al., 1989). Homologs of the $c z c$ genes, called $c z r$, which conferred cadmium and zinc resistance, were recently identified in the chromosome of Ps. aeruginosa and appear to be highly conserved in environmental isolates of that species (Hassan et al., 1999). In addition, a homolog of the cadABC operon, found previously only in Grampositive bacteria, was identified in the Gramnegative bacterium Stenotrophomonas maltophilia (Alonso et al., 2000). The flanking insertion sequences and unusual $\mathrm{G}+\mathrm{C}$ content of the locus was suggestive of its transfer from Gram-positive bacteria. Recently, the genome sequences of several Gram-negative bacteria have revealed homologs of cadA. Functional analysis of their role in metal resistance has been conducted in Helicobacter pylori (Herrmann et al., 1999) and with the E. coli cadA homolog, zntA (Rensing et al., 1997). ZntA was originally described as a zinctransporting ATPase, but it also confers resistance to cadmium and lead. Recent studies proposed that CadA of S. aureus and ZntA of E. coli are $\mathrm{Pb}(\mathrm{II})$-transporting ATPases (Rensing et al., 1999; Sharma et al., 2000) In contrast to cadA of Grampositive bacteria, zntA expression is regulated by $z n t R$, encoding a MerR homolog, but located in another region of the E. coli chromosome from zntA (Outten et al., 1999). Metallothioneins are small, cysteine-rich proteins (Hamer, 1986), synthesized under heavy metal stress conditions that have been found in both prokaryotes (Olafson et al., 1988) and eukaryotes (Palmiter, 1998). The only known bacterial metallothionein locus, designated smt, that has been cloned and structurally characterized is that in Synechococcus sp. strain PCC 6301 (Robinson et al., 1990) and in strain PCC 7942 (Huckle et al., 1993). The smt locus consists of two divergently transcribed genes, smtA and smtB (Huckle et al., 1993), and mediates resistance to zinc and cadmium (Turner et al., 1995).

In conclusion, although some heavy metals are important and essential trace elements, at high concentrations, such as those found in many environments today, most can be toxic to microbes. Microbes have adapted to tolerate the presence of metals or can even use them to grow. Thus, a number of interactions between microbes and metals have important environmental and health implications. Some implications are useful, such as the use of bacteria to clean up metalcontaminated sites. Bacteria exhibiting multiple plant health and development enhancing traits coupled with the excellent potential to resist the heavy metal stress in soils, may eventually find wide-ranging applications in the development of 
bioremediation strategies for heavy metal decontamination. In heavily contaminated soils where the metal content exceeds the limit of plant tolerance, it may be possible to treat plants with PGPB thereby stabilizing, re-vegetating, and remediating metalpolluted soils. In addition, the application of the heavy metal resistant and plant beneficial bacteria can be considered as bioremediating tools with great economical and ecological relevance. Other implications are not as beneficial, as the presence of metal tolerance mechanisms may contribute to the increase in antibiotic resistance. Overall, it is most important to remember that what we put into the environment can have many effects, not just on humans, but also on the environment and on the microbial community on which all other life depends.

\section{References}

Abouhamad, W.N., M. Manson, M.M. Gibson, and C.F. Higgins. 1991. Peptide transport and chemotaxis in Escherichia coli and Salmonella typhimurium: characterization of the dipeptide permease (Dpp) and the dipeptidebinding protein. Mol. Microbiol. 5:1035-1047.

Adriano, D.C. 2001. Trace Elements in Terrestrial Environments: Biogeochemistry, Bioavailability and Risks of Metals. (Springer Verlag), New York, 135-167.

Ahemad, M., Khan, M.S. 2012. Effect of fungicides on plant growth promoting activities of phosphate solubilizing Pseudomonas putida isolated from mustard (Brassica campestris) rhizosphere. Chemosphere 86: 45-950.

Ahemad, M., Khan, M.S. 2009. Effect of insecticide-tolerant and plant growth promoting Mesorhizobium on the performance of chickpea grown in insecticide stressed alluvial soils. $J$. Crop Sci. Biotechnol. 12: 213-222.
Ahemad, M., Kibret, M. 2013. Recent trends in microbial biosorption of heavy metals: a review. Biochem. Mol. Biol. 1, 19-26.

Ahemad, M., Malik, A. 2011. Bioaccumulation of heavy metals by zinc resistant bacteria isolated from agricultural soils irrigated with wastewater. Bacteriol. J. 2: 12-21.

Ahemad, M. 2014. Bacterial mechanisms for $\mathrm{Cr}(\mathrm{VI})$ resistance and reduction: an overview and recent advances. Folia Microbiol., $\quad$ 9, 257-268, http://dx.doi.org/10.1007/s12223-0140304-8.

Ahemad, M. 2012. Implications of bacterial resistance against heavy metals in bioremediation: a review. IIOAB J. 3, 39-46.

Alkorta, I., Herna'ndez-Allica Becerril, J.M., Amezaga, I., Albizu, I., Garbisu, C. 2004. Recent findings on the phytoremediation of soils contaminated with environmentally toxic heavy metals and metalloids such as zinc, cadmium, lead, and arsenic. Rev. Environ. Sci. Biotechnol., 3, 71-90.

Alloway, B.J. Introduction. In: Alloway, B.J. (Ed. Heavy Metals in Soils. (Blackie Academic \& Professional, New York 1995) pp. 3-9

Alonso, A., SaÂnchez, P., MartôÂnez, J.L. 2000. Stenotrophomonas maltophilia D457R contains a cluster of genes from gram-positive bacteria involved in antibiotic and heavy metal resistance. Antimicrob Agents Chemother., 44, 1778-1782

Beach, L.R., Palmiter, R.D. 1981. Amplification of the metallothionein-I gene in cadmium-resistant mouse cells. Proc. Natl. Acad. Sci., 78, 2110-2114.

Biro’, B., Bayoumi, H.E., Balazsy, S., Kecskes, M. 1995. Metal sensitivity of some symbiotic $\mathrm{N}$-fixing bacteria and Pseudomonas strains. Acta Biol. Hung. 46, 9-16. 
Bishop, P.L. 2002. Pollution Prevention: Fundamentals and Practice. (Tsinghua University Press, Beijing, China.) 157.

Bloom, S.L., and D.B. Zamble. 2004. Metalselective DNA-binding response of Escherichia coli NikR. Biochemistry, 43:10029-10038.

Chivers, P. T., and R. T. Sauer. 2000. Regulation of high affinity nickel uptake in bacteria. $\mathrm{Ni}$-dependent interaction of NikR with wild-type and mutant operator sites. J. Biol. Chem. 275:19735-19741.

Crupper, S.S., Worrell, V., Stewart, G.C., Iandolo, J.J. 1999. Cloning and expression of cadD, a new cadmium resistance gene of Staphylococcus aureus. J. Bacteriol., 181: 4071-4075

De Pina, K., V. Desjardin, M.-A. MandrandBerthelot, G. Giordano, and L.-F. Wu.. Isolation and characterization of the nikR gene encoding a nickel-responsive regulator in Escherichia coli. J. Bacteriol., 181: 670-674.

Degen, O., and Eitinger, T. 2002. Substrate specificity of nickel/cobalt permeases: insights from mutants altered in transmembrane domains I and II. $J$. Bacteriol. 184: 3569-3577.

Degen, O., M. Kobayashi, S. Shimizu, and T. Eitinger.. Selective transport of divalent cations by transition metal permeases: the Alcaligenes eutrophus HoxN and the Rhodococcus rhodochrous NhlF. Arch. Microbiol., 171: 139-145

Diaz-Ravina, M., Baath, E. Development of metal tolerance in soil bacterial communities exposed to experimentally increased metal levels. Appl. Environ. Microbiol., 62, 2970-2977

Diels, L., Dong, Q., Van der Lelie, D., Baeyens W., Mergeay M. The czc operon of Alcaligenes eutrophus $\mathrm{CH} 34$. From resistance mechanism to the removal of heavy metals. J. Ind. Microbiol., 14, 142153.

Diels, L., Spaans, P.H., Van Roy, S., Hooyberghs, L., Ryngaert, A., Wouters, H., Walter, E., Winters, J., Macaskie, L.,
Finlay, J., Pernfuss, B., Woebking, H., Pumpel, T., Tsezos, M. Heavy metals removal by sand filters inoculated with metal sorbing and precipitating bacteria. Hydrometallurgy, 71, 235-241.

Dimkpa, C., Svatos, A., Merten, D., Buchel, G., Kothe, E. 2008. Hydroxamate siderophores produced by Streptomyces acidiscabies E13 bind nickel and promote growth in cowpea (Vigna unguiculata L.) under nickel stress. Can. J. Microbiol., 54, 163-172

Eberz G., Eitinger T., Friedrich B. 1989. Genetic determinants of a nickelspecific transport system are part of the plasmid-encoded hydrogenase gene cluster in Alcaligenes eutrophus. J. Bacteriol., 171: 1340-1345

Eitinger, T., J. Suhr, J. Moore, and J. A. C. Smith.. Secondary transporters for nickel and cobalt ions: theme and variations. BioMetals, 18: 399- 405.

Endo, G., Silver S. CadC, the transcriptional regulatory protein of the cadmium resistance system of Staphylococcus aureus plasmid pI258. J Bacteriol., 177, 4437-4441

García-Domínguez, M., Lopez-Maury, L., Florencio, F.J., and Reyes, J.C.. A gene cluster involved in metal homeostasis in the cyanobacterium Synechocystis sp. Strain PCC 6803. J. Bacteriol., 182: 1507-1514.

Gilis, A., Corbisier, P., Baeyens, W., Taghavi, S., Mergeay, M., van der Lelie, D. Effect of the siderophore alcaligin $\mathrm{E}$ on the bioavailability of $\mathrm{Cd}$ to Alcaligenes eutrophus CH34. J. Ind. Microbiol. Biotechnol., 20, 61-68.

Giller, K.E., Witter, E., McGrath, S.P. Toxicity of heavy metals to microorganisms and microbial process in agricultural soils: a review. Soil Biol. Biochem. 30, 1389-1414

Grass, G., Fan, B., Rosen, B.P., Lemke, K., Schlegel, H.G. and Rensing, C. Nre B from Achromobacter xylosoxidans 31A Is a Nickel-Induced Transporter Conferring Nickel Resistance. Jour. of 
Bacteriol., $183(9$. 2001 p. $2803 \pm 2807$ doi: 10.1128/JB.183.9.2803 \pm 2807.2001

Gray, E.J., Smith, D.L. Intracellular and extracellular PGPR: commonalities and distinctions in the plant-bacterium signaling processes. Soil Biol. Biochem. 37, 2005) 395-412.

Haferburg, G., Kothe, E. Microbes and metals: interactions in the environment. J. Basic Microbiol. 47, 2007 453-467

Hamer D.H. Metallothioneins. Annu. Rev. Biochem. 55, 1986 913-951

Hassan, M.E.T., van der Lelie D., Springael D., Römling N., Ahmed N., Mergeay M. Identification of a gene cluster, czr, involved in cadmium and zinc resistance in Pseudomonas aeruginosa. Gene 238, 1999 417-425

Hebbeln, P., and T. Eitinger.. Heterologous production and characterization of bacterial nickel/cobalt permeases. FEMS Microbiol. Lett. 230, 2004 :129- 135.

Herrmann L., Schwan D., Garner R., Mobley H.L.T., Haas R., Schafer K.P., Melchers K. Helicobacter pylori cadA encodes an essential Cd(II)-Zn(II)-Co(II) resistance factor influencing urease activity. Mol Microbiol 33, 1999 524-536

Hewitt, E.J. In: Robb, D.A., Pierpoint, E.S. (Eds. Tals and Micronutrients: Uptake and Utilization by Plants. (Academic Press, London 1983) pp. 277-300

Hmiel, S.P., Snavely M.D., Florer J.B., Maguire M.E., Miller C.G. Magnesium transport in Salmonella typhimurium: genetic characterization and cloning of three magnesium transport loci. $J$ Bacteriol 171,(1989 : 4742-4751

Huckle, J.W., Morby A.P., Turner J.S., Robinson N.J. Isolation of a prokaryotic metallothionein locus and analysis of transcriptional control by trace metal ions. Mol Microbiol 7, 1993 177-187

Hutchinson, T.C., Symington, M.S. Persistence of metal stress in a forested ecosystem near Sudbury, 66 years after closure of the O'Donnell roast bed. $J$. Geochem. Explor. 58, 1997 323-330
Ilieva, A., Vasileva, V. Effect of presowing treatment of seeds with insecticides on parameters related to nodulation and nitrate reduction in soybean (Glycine max (L.) Merr.). J. Cent. Eur. Agric. 15, 2014 23-32

Jing, Y., He, Z., Yang, X. Role of soil rhizobacteria in phytoremediation of heavy metal contaminated soils. $J$. Zhejiang Univ. Sci. B 8, 2007 192-207

Jubier-Maurin, V., A. Rodrigue, S. OuahraniBettache, M. Layssac, M. A. MandrandBerthelot, S. Kohler, and J. P. Liautard.. Identification of the nik gene cluster of Brucella suis: regulation and contribution to urease activity. $J$. Bacteriol. 183, 2001 :426-434.

Kabata-Pendias, A., Pendias, H. Trace Elements in Soils and Plants. (CRC Press, Boca Raton, FL 2001 67-88

Kaur, P., Ross K., Siddiqui R.A., Schlegel H.G. Nickel resistance of Alcaligenes denitrificans strain $4 \mathrm{a}-2$ is chromosomally coded. Arch Microbiol 154, $1990: 133-138$

Kosev, V., Vasileva, V. Some studies on the selection of forage pea (Pisum sativum L.) to increase the symbiotic nitrogen fixing potential. Int. J. Pharm. Life Sci. 5, 2014) 3570-3579

Kotrba, P., Najmanova, J., Macek, T., Ruml, T., Mackova, M. Genetically modified plants in phytoremediation of heavy metal and metalloid soil and sediment pollution. Biotechnol. Adv. 27, 2009) 799-810

Laddaga, R.A., Silver S. Cadmium uptake in Escherichia coli K-12. J Bacteriol 162, 1985 1100-1105

Lebrun, M., Audurier A., Cossart P. Plasmidborne cadmium resistance genes in Listeria monocytogenes are present on Tn5422, a novel transposon closely related to Tn917. J Bacteriol 176, 1994 3049-3061

Lebrun, M., Loulergue J., Chaslus-Dancla E., Audurier A. Plasmids in Listeria monocytogenes in relation to cadmium 
resistance. Appl Environ Microbiol 58, 1992 3183-3186

Lee, Y.K., Chang, H.H., Lee,H.J., Park,H., Lee, K.H. and Joe M.H. Isolation of a novel plasmid, pNi15, fromEnterobacter sp. Ni15 containing a nickel resistance gene. FEMS Microbiol Lett 257,(2006 177-181.

Levdikov, V.M., E.V. Blagova, J. A. Brannigan, L. Wright, A. A. Vagin, and A. J. Wilkinson.. The structure of the oligopeptide-binding protein, AppA, from Bacillus subtilis in complex with a nonapeptide. J. Mol. Biol. 345, 2005 879-892.

Liesegang, H., Lemke K., Siddiqui R.A., Schlegel H.G.Characterization of the inducible nickel and cobalt resistance determinant cnr from pMOL28 of Alcaligenes eutrophus $\mathrm{CH} 34 . \quad J$ Bacteriol 175, 1993 : 767-778

Lohmeyer M., Friedrich, C.G., Nickel transport in Alcaligenes eutrophus. Arch Microbiol 149, 1987 : 130-135

Lovley, D.R. Bioremediation of organic and metal contaminants with dissimilatory metal reduction. J. Ind. Microbiol. 14, 1995 85-93

Madhaiyan, M., Poonguzhali, S., Sa, T. Metal tolerating methylotrophic bacteria reduces nickel and cadmium toxicity and promotes plant growth of tomato (Lycopersicon esculentum L.). Chemosphere 69, 2007 220-228

McEntee, J.D., Woodrow J.R., Quirk A.V.Investigation of cadmium resistance in an Alcaligenes sp. Appl Environ Microbiol 51,(1986 515-520

Mergeay, M. Plasmids for heavy metal resistance in Alcaligens eutrophus: Mechanisms and applications. In: Ahmed N., Ishaq M., Khan O.Y., Sarwar F. (eds). Biotechnology for Environment and Agriculture. (B.C.C. and $\mathrm{T}$ Press, Univ. of Karachi).pp: (1995 165-177

Mergeay, M., Nies D.H., Schlegel H.G., Gerits J., Charles P., van Gijsegem F. Alcaligenes eutrophus $\mathrm{CH} 34$ is a facultative chemolithotroph with plasmid-bound resistance to heavy metals. J Bacteriol 162, 1985 : 328-334

Mikolay, A. and Nies, D.H.. The ABCtransporter AtmA is involved in nickel and cobalt resistance of Cupriavidus metallidurans strain CH34. Anton. V. Lee. 4, 2009 37-40. doi 10.1007/s10482008-9303-6

Mitra, R.S., Bernstein I.A.Nature of the repair process associated with the recovery of Escherichia coli after exposure to $\mathrm{Cd}^{2+}$. Biochem Biophys Res Commun 21, 1977 74:1450-1455

Navarro, C., Wu L. F., and MandrandBerthelot M. A... The nik operon of Escherichia coli encodes a periplasmic binding-protein-dependent transport system for nickel. Mol. Microbiol. 9,(1993 1181-1191

Nies, D.H., Nies A., Chu L., Silver S.Expression and nucleotide sequence of a plasmid-determined divalent cation efflux system from Alcaligenes eutrophus. Proc Natl Acad Sci USA 86, 1989 : 7351-7355

Nies, D.H., Silver, S. Ion efflux systems involved in bacterial metal resistances. $J$. Ind. Microbiol. 14, 1995 186-199

Nies, D.H. Microbial heavy-metal resistance. Appl. Microbiol. Biotechnol. 51, 1999) 730-750

Nucifora, G., Chu L., Misra T.K., Silver S.Cadmium resistance from Staphylococcus aureus plasmid pI258 cadA gene results from a cadmiumefflux ATPase. Proc Natl Acad Sci USA 86, 1989 3544-3548

Olafson, R.W., Mccubbin W.D., Kay C.M. Primary and secondary- structural analysis of a unique prokaryotic metallothionein from a Synechococcus sp. cyanobacterium. Biochem J 251, 1988 691-699

Outten, C.E., Outten F.W., O'Halloran T.V. DNA distortion mechanism for transcriptional activation by ZntR, a $\mathrm{Zn}(\mathrm{II})$-responsive MerR homologue in 
Escherichia coli. J Biol Chem 274, 1999 37517-37524

Pajuelo, E., Ignacio, D., Llorente, R., Dary, M., Palomares, A.J. Toxic effects of arsenic on Sinorhizobium-Medicago sativa symbiotic interaction. Environ. Pollut. 154, 2008 203-211

Palmiter, R.D. The elusive function of metallothioneins. Proc Natl Acad Sci USA 95, 1998 8428-8430

Rajkumar, M., Ae, N., Prasad, M.N.V., Freitas, H. Potential of siderophoreproducing bacteria for improving heavy metal phytoextraction. Trends Biotechnol. 28, 2010 142-149

Rajkumar, M., Nagendran, R., Kui, J.L., Wang, H.L., Sung, Z.K. Influence of plant growth promoting bacteria and $\mathrm{Cr}(\mathrm{VI})$ on the growth of Indian mustard. Chemosphere 62, 2006 741-748

Ranjard, L., Nazaret, S., Cournoyer, B. Freshwater bacteria can methylate selenium through the thiopurine methyltransferase pathway. Appl. Environ. Microbiol. 69, $2003 \quad 3784$ 3790.

Rensing, C., Mitra B., Rosen B.P.The zntA gene of Escherichia coli encodes a $\mathrm{Zn}$ (II)-translocating P-type ATPase. Proc Natl Acad Sci USA 94, 1997 14326-14331

Robinson, N.J., Gupta A., Fordham-Skelton A.P., Croy R.R.D., Whitton B.A., Huckle J.W. Prokaryotic metallothionein gene characterization and expression: chromosome crawling by ligation-mediated PCR. Proc $R$ Soc (London B) 242, 1990 241-247

Rodrigue, A., Effantin, G. and Berthelot, M.A.M. Identification of rcnA (yohM a Nickel and Cobalt Resistance Gene in Escherichia coli. Jour. Bacteriol., 187(8 (2005 :p. 2912-2916

Schmidt, T., Stoppel R.D., Schlegel H.G. High-level nickel resistance in Alcaligenes xylosoxydans 31A and Alcaligenes eutrophus KT02. Appl Environ Microbiol 57, 1991 : 33013309.
Schmidt, T., Schlegel, H.G. Nickel and cobalt resistance of various bacteria isolated from soil and highly polluted domestic and industrial wastes. FEMS Microbiol Ecol 62, 1989 : 315-328

Sebbane, F., M.A. Mandrand-Berthelot, and M. Simonet.. Genes encoding specific nickel transport systems flank the chromosomal urease locus of pathogenic yersiniae. J. Bacteriol. 184, 2002 :57065713.

Sharma, R., Rensing, C., Rosen, B.P., Mitra, B. The ATP hydrolytic activity of purified $\mathrm{ZntA}$, a $\mathrm{Pb}(\mathrm{II}) / \mathrm{Cd}(\mathrm{II}) / \mathrm{Zn}$ (II)translocating ATPase from Escherichia coli. J Biol Chem 275, 2000 3873-3878

Shier, W.T. Metals as toxins in plants. $J$. Toxicol. Toxin Rev. 13, 1994) 205-216

Silver, S. Bacterial resistances to toxic metal ions - a review. Gene 179, 1996 9-19

Silver, S., Phung L.T.Bacterial heavy metal resistance: new surprises. Annu Rev Microbiol 50, 1996 753-789

Smith, D.H. R factors mediate resistance to mercury, nickel and cobalt. Science 156, 1967 : 1114-1116

Stahler, F.N., Odenbreit, S., Haas, R., Wilrich, J., Van Vliet, A.H., Kusters, J.G., Kist, M. and Bereswill, S. The novel Helicobacter pylori CznABC metal efflux pump is required for cadmium, zinc, and nickel resistance, urease modulation, and gastric colonization. Infect Immun, 74, 2006 3845-3852.

Stoppel, R.D., Meyer M., Schlegel H.G.The nickel resistance determinant cloned from the enterobacterium Klebsiella oxytoca: conjugational transfer, expression, regulation and DNA homologies to various nickel- resistant bacteria. Biometals 8: 70-79.

Timotius, K., Schlegel H.G. Aus Abwa“ssern isolierte nickelresistente Bakterien. Nachrichten Akad. Wiss. Go"ttingen. II. Math-Physik Kl 3, 1987 : 15-23

Turner, J.S., Robinson N.J., Gupta A. Construction of $\mathrm{Zn}^{2+} / \mathrm{Cd}^{2+}$-tolerant cyanobacteria with a modified metallothionein divergon: further 
analysis of the function and regulation of smt. J. Ind. Microbiol., 14: 259- 264. Tynecka, Z., Gos, Z., Zajac, J. 1981. Energydependent efflux of cadmium coded by a plasmid resistance determinant in Staphylococcus aureus. J. Bacteriol., 147: 305-312

Wang, J., Chen, C. 2006. Biosorption of heavy metals by Saccharomyces cerevisiae: a review. Biotechnol. Adv., 24: 427-451.

Wang, Y.T., Shen, H. Bacterial reduction of hexavalent chromium. J. Ind. Microbiol., 14: 159-163

Wani, P.A., Khan, M.S., Zaidi, A. Chromiumreducing and plant growth-promoting
Mesorhizobium improves chickpea growth in chromium-amended soil. Biotechnol. Lett., 30: 159-163.

Wani, P.A., Khan, M.S. 2010. Bacillus species enhance growth parameters of chickpea (Cicer arietinum L.) in chromium' stressed soils. Food Chem. Toxicol., 48: 3262-3267.

Witte, W., Green, L., Misra, T.K., Silver, S. 1986. Resistance to mercury and to cadmium in chromosomally resistant Staphylococcus aureus. Antimicrob. Agents Chemother., 29: 663-669.

\section{How to cite this article:}

Santanu Maitra. 2016. Study of Genetic Determinants of Nickel and Cadmium Resistance in Bacteria-A Review. Int.J.Curr.Microbiol.App.Sci. 5(11): 459-471. doi: http://dx.doi.org/10.20546/ijcmas.2016.511.053 